\title{
Persistent suborbital climate variability in marine isotope stage 5 and Termination II
}

\author{
Delia W. Oppo, Lloyd D. Keigwin, Jerry F. McManus \\ Department of Geology and Geophysics, Woods Hole Oceanographıc Institution, Woods Hole, Massachusetts
}

James L. Cullen

Department of Geological Sciences, Salem State College, Salem, Massachusetts

\begin{abstract}
New surface water records from two high sedimentation rate sites, located in the western subtropical North Atlantic near the axis of the Gulf Stream, provide clear evidence of suborbital climate variations through marine isotope stage (MIS) 5 persisting even into the warm peak of the interglaciation (substage $5 \mathrm{e}$ ). We found that the amplitude of suborbital climate oscillations did not vary significantly for the whole of MIS 5, implying that ice volume has little or no influence on the amplitude of suborbital climate variability in this region. Although some records suggest that longer suborbital variations (4-10 kyr) during MIS 5 are linked to deepwater changes, none of the existing records is of sufficient resolution to assess if a linkage occurred for oscillations shorter than $4 \mathrm{kyr}$. However, when examined in conjunction with published data from the Norwegian Sea, new evidence from the subpolar North Atlantic suggests that coupled surface-deepwater oscillations occurred during the penultimate deglaciation. This supports the hypothesis that during glacial and deglacial times, ocean-ice interactions and deepwater variability amplify suborbital climate change at higher latitudes. We suggest that during the penultimate deglaciation the North Atlantic deepwater source varied between Nordic Sea and open North Atlantic locations, in parallel with surface temperature oscillations.
\end{abstract}

\section{Introduction}

Abundant evidence from marine and terrestrial paleoclimatic archives indicates that climate changes occur more frequently than can be explained by a linear response to cyclical changes in orbital geometry. Ice core and marine records reveal several timescales of higher-frequency climate variability. For example, during the last glacial cycle, variations in Greenland ice core $\delta^{18} \mathrm{O}$, equivalent to $5^{\circ}-12^{\circ} \mathrm{C}$ variations in air temperature, occurred on $2-3 \mathrm{kyr}$ timescales [Dansgaard et al., 1971; Oeschger et al., 1984], and North Atlantic sea surface temperature (SST) and ice rafting varied on 1-2 kyr timescales [Bond et al., 1997, 1999]. The repeat time of Heinrich events, episodes of massive ice discharge into the North Atlantic, was 5-10 kyr [Heinrich, 1988; Bond et al., 1993]. The amplitude of climate variations on each of these timescales appears to vary with time. For example, analysis of the Greenland ice core $\delta^{18} \mathrm{O}$ record suggests that high-amplitude $1-2 \mathrm{kyr}$-long oscillations are prevalent during the marine isotope stage (MIS) 3 portion of the last glacial interval but appear dampened during the previous interglacial, MIS 5 [e.g., Schulz et al., 1999]. Until this work, only longer timescale variations (4-10 kyr) characterize MIS 5 . Thus the length of the cycles may depend on the resolution of the record, the region, and the climate variable.

The origin of suborbital climate oscillations is not understood. Because of their prominence in glacial sequences, glacial processes, such as internal ice sheet dynamics and ice/ocean interactions, have emerged as likely candidates [MacAyeal, 1993a, 1993b]. While the

\section{Copynght 2001 by the American Geophysical Union.}

Paper number 2000PA000527.

0883-8305/01/2000PA000527\$12.00 presence of large ice sheets may be important in the development of high-amplitude variability on 5-10 kyr timescales [Wara et al., 2000], a growing body of evidence indicates that $1-3 \mathrm{kyr}$ oscillations persist into the Holocene [e.g., Alley et al., 1997; Bianchi and McCave, 1999; Bond et al., 1997; Campbell et al., 1998; Keigwin and Jones, 1989; O'Brien et al., 1995; Sirocko et al., 1996]. These studies suggest that although the presence of large ice sheets may amplify 1-3 kyr climate instability, it is not the cause of such instability. Deepwater variability and associated heat redistribution have emerged as leading mechanisms for $1-3 \mathrm{kyr}$ climate variations, but the underlying forcing is not known [e.g., Broecker et al., 1990; Alley et al, 1999].

In light of recent evidence that Holocene and deglacial climate oscillations are a continuation of the regular sequence of millennial climate oscillations [Bond et al., 1997; Mayewski et al., 1997], the absence of evidence for 1-3 kyr oscillations during MIS 5 is puzzling. To evaluate further the occurrence and origin of suborbital climate variability within MIS 5, we generated detailed records of surface hydrography from the westem subtropical North Atlantic. Suborbital variability during MIS 3 is well documented in this region [Keigwin and Boyle, 1999; Sachs and Lehman, 1999]. We compare the new high-resolution records to detailed records from high-latitude North Atlantic sites (Figure 1). ${ }^{1}$

Our North Atlantic records also enable us to evaluate the occurrence and nature of suborbital-scale climate variations during the penultimate deglaciation. There is continued support for a strong difference between the last deglaciation ("Termination I" after Broecker

\footnotetext{
'Supporting data for the figures are available electronically at World Data Center-A for Paleoclimatology, NOAA/NGDC, 325 Broadway, Boulder, CO 80303. (e-mail: paleo@mail.ngdc.noaa gov; URL: http://www.ngdc.noaa. gov/paleo)
} 


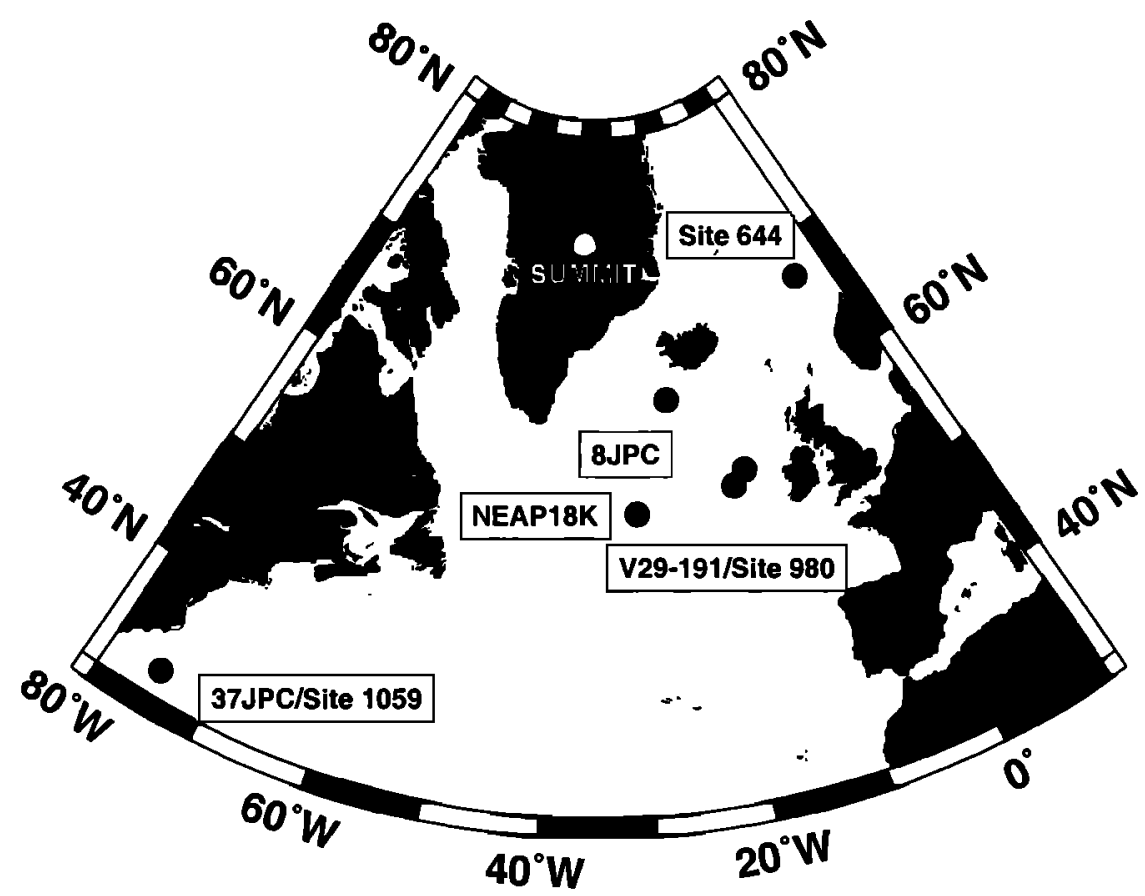

Figure 1. Location of the Summit (GISP 2 and GRIP) ice cores and of marine sites discussed: site $980\left(55^{\circ} \mathrm{N}, 15^{\circ} \mathrm{W}, 2179 \mathrm{~m}\right)$, V29$191\left(54^{\circ} \mathrm{N}, 17 \mathrm{~W}, 2370 \mathrm{~m}\right), 8 \mathrm{JPC}\left(61^{\circ} \mathrm{N}, 25^{\circ} \mathrm{W}, 1917 \mathrm{~m}\right)$, site $1059\left(32^{\circ} \mathrm{N}, 75^{\circ} \mathrm{W}, 2985 \mathrm{~m}\right), 37 \mathrm{JPC}\left(32^{\circ} \mathrm{N}, 75^{\circ} \mathrm{W}, 2972 \mathrm{~m}\right), \mathrm{NEAP} 18 \mathrm{~K}$ $\left(53^{\circ} \mathrm{N}, 30^{\circ} \mathrm{W}, 3175 \mathrm{~m}\right)$, and site $644\left(67^{\circ} \mathrm{N}, 4^{\circ} \mathrm{E}, 1227 \mathrm{~m}\right)$.

and Donk [1970]) and the penultimate deglaciation (Termination II). Earlier studies provided evidence for a reduction in North Atlantic Deep Water (NADW) production that persisted throughout the penultimate deglaciation [Adkins et al., 1997; Duplessy and Shackleton, 1985; Oppo et al., 1997; Sarnthein and Tiedemann, 1990] and that subpolar North Atlantic surface waters remained cold throughout the deglaciation [Ruddiman et al., 1980; Oppo et al., 1997]. More recent studies suggest that surface oscillations in the subpolar North Atlantic, south of the Nordic Seas, were less pronounced during Termination II than during Termination I, consisting of a "pause" rather than a climatic reversal [Lototskaya and Ganssen, 1999]. Importantly, however, these recent studies demonstrate that cyclic variations in deepwater production occurred during Termination II [e.g., Rasmussen et al., 1999; Lototskaya and Ganssen, 1999], as was also the case during Termination I [Boyle and Keigwin, 1987; Lehman and Keigwin, 1992].

\section{Materials and Methods}

During Ocean Drilling Program (ODP) Leg 172 in the subtropical western North Atlantic, site 1059 was cored on a small sediment drift near the ridge crest of the Blake Outer Ridge [Keigwin et al., 1998]. We sampled hole 1059A (hereafter referred to as site 1059 ; $31^{\circ} 40.46^{\prime} \mathrm{N}, 75^{\circ} 25.13^{\prime} \mathrm{W}, 2985 \mathrm{~m}$ ) and nearby drift site KNR $140-$ $37 \mathrm{JPC}$ (hereafter referred to as $37 \mathrm{JPC} ; 31^{\circ} 41.41^{\prime} \mathrm{N}, 75^{\circ} 25.81^{\prime} \mathrm{W}$, $2972 \mathrm{~m}$ ). Although these sites are only $-3 \mathrm{~km}$ apart, site 1059 has a much higher sedimentation rate (Figure 2). We compare the detailed records from this region located just southwest of the axis of the Gulf Stream to published records [McManus et al., 1994, 1999] from core V19-191 $\left(54^{\circ} \mathrm{N}, 17^{\circ} \mathrm{W}, 2370 \mathrm{~m}\right)$ and site $980\left(55^{\circ} \mathrm{N}\right.$, $15^{\circ} \mathrm{W}, 2179 \mathrm{~m}$ ), both located to the west of the British Isles on the
Feni Drift, and from core EW9302-8JPC (hereafter referred to as $8 J P C ; 61^{\circ} \mathrm{N}, 25^{\circ} \mathrm{W}, 1917 \mathrm{~m}$ ) [Oppo et al., 1997], located southeast of Iceland on the Bjorn Drift. We resampled $8 \mathrm{JPC}$ at $0.5 \mathrm{~cm}$ intervals across the penultimate deglaciation to increase the resolution of existing records during that time [Oppo et al., 1997]. Previously unpublished faunal data from site 980 are also presented. We also present deepwater records from site 1059 and core JPC 37 for MIS 5 and from 1059, 8JPC, and 980 for Termination II. For completeness, we include published data [Chapman and Shackleton, 1999] from core NEAP18K $\left(53^{\circ} \mathrm{N}, 30^{\circ} \mathrm{W}, 3725 \mathrm{~m}\right)$, located to the southwest of the other subpolar North Atlantic sites.

In addition to providing spatial coverage, these sites intersect the two main water masses that replaced NADW during glacial times [e.g., Bertram et al., 1995; Boyle and Keigwin, 1987; Oppo and Lehman, 1993]. During glacial times, core 8JPC was located within nutrient-depleted (high $\delta^{13} \mathrm{C}$ ) Glacial North Atlantic Intermediate Water (GNAIW) or within the sharp gradient that separated GNAIW from the deeper, more nutrient-rich (lower $\delta^{13} \mathrm{C}$ ) water mass that contained a significant proportion of Southern Ocean Water (SOW). At $2179 \mathrm{~m}$, ODP site 980 lay within the lower portion of the mixing gradient between water masses, and site 1059 , core 37 JPC $(-2980 \mathrm{~m})$ and NEAP18K (3275 m) lay within the deeper, more nutrient-rich water mass.

At all locations, $\delta^{18} \mathrm{O}$ records of the benthic foraminifera $\mathrm{Cibici}$ doides wuellerstorfi ( $>150 \mu \mathrm{m}$; one to two specimens) provide age control. The $\delta^{13} \mathbf{C}$ records of $\boldsymbol{C}$. wuellerstorfi are used to estimate changes in deepwater nutrient content. The records of the percentage of the polar planktic foraminifera Neogloboquadrina pachyderma (left coiling, or sinistral (s.)) in the planktic assemblage and of the $\delta^{18} \mathrm{O}$ of Neogloboquadrina pachyderma (right coiling, or dextral (d.)) (150-250 $\mu \mathrm{m} ; 8-10$ specimens) provide complimentary estimates 

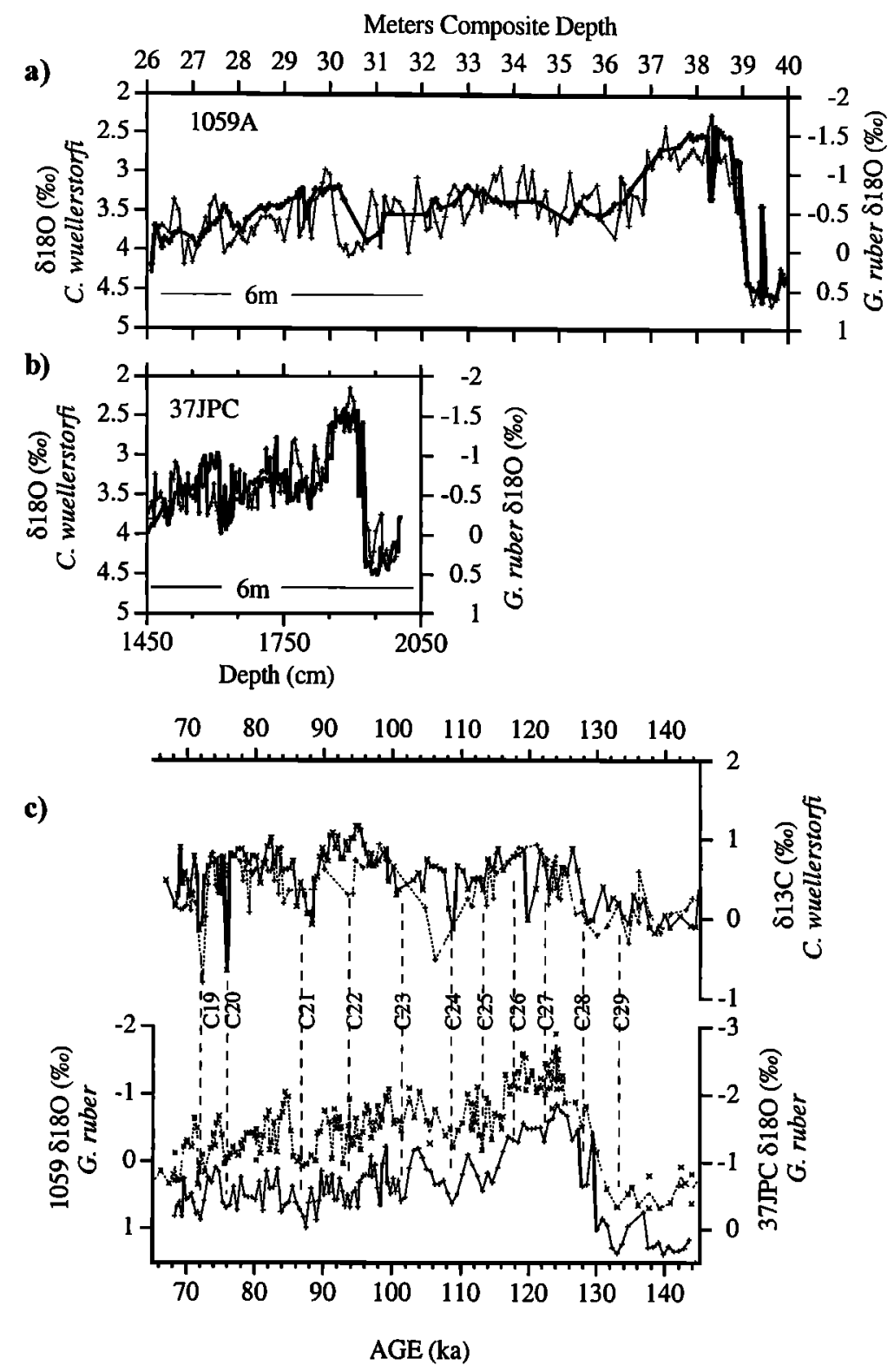

Figure 2. (a) Site 1059 and (b) KNR 140-37JPC planktic (Globigerinoides ruber) and benthic (Cibicidoides wuellerstorfi) $\delta^{18} \mathrm{O}$ records, given as thin and thick lines, respectively. (c) $G$. ruber $\delta^{18} \mathrm{O}$ and benthic (C. wuellerstorfi) $\delta^{13} \mathrm{C}$ records from site 1059 (dotted line) and core 37JPC (solid line) on common timescales.

of changing sea surface conditions at the two subpolar sites. Whereas variations in percent $N$. pachyderma (s.) are dominated by temperature changes, they can only capture SST temperature changes over a relatively limited range [Bé and Tolderlund, 1971; Kellogg, 1980]. In contrast, the $\delta^{18} \mathrm{O}$ of $N$. pachyderma (d.) is a better recorder of the full glacial-interglacial range of SST change in the subpolar North Atlantic but is also affected by variations in the $\delta^{18} \mathrm{O}$ of surface waters [McManus et al., 1999; Oppo et al., 1997, 1998]. At Feni Drift the $\delta^{18} \mathrm{O}$ of $N$. pachyderma (d.) closely followed millennial variations in the relative abundance of the temperature-sensitive foraminifera $N$. pachyderma (s.) during the MIS 11/10 transition, underscoring the utility of the $\delta^{18} \mathrm{O}$ proxy in this region [Oppo et al., 1998]. The number of lithic grains $(>150 \mu \mathrm{m})$ in each sample from the subpolar North Atlantic sites provides a measure of ice-rafted detritus (IRD). The results are expressed as the number of IRD grains per gram of dry sediment (number per gram) and as IRD grains relative to total entities $(>150 \mu \mathrm{m})$ in the sample (percent IRD). At the subtropical sites we used the $\delta^{18} \mathrm{O}$ of Globigerinoides ruber (212-250 $\mu \mathrm{m}, 8-10$ specimens at site 1059 and 150-250 $\mu \mathrm{m}, \sim 20$ specimens at $37 \mathrm{JPC}$ ) to estimate sea surface changes. Studies of nearby cores from the Bermuda Rise suggest that $G$. ruber $\delta^{18} \mathrm{O}$ oscillations in this region during MIS 3 are largely due to SST variations and that they can be correlated to air temperature variations in the Greenland ice cores [Keigwin and Boyle, 1999; Sachs and Lehman, 1999]. Except for the records from NEAP18K, isotopic measurements were made at the Woods Hole Oceanographic Insti- 
Site 980

2179m, Feni Drift

a)

b)

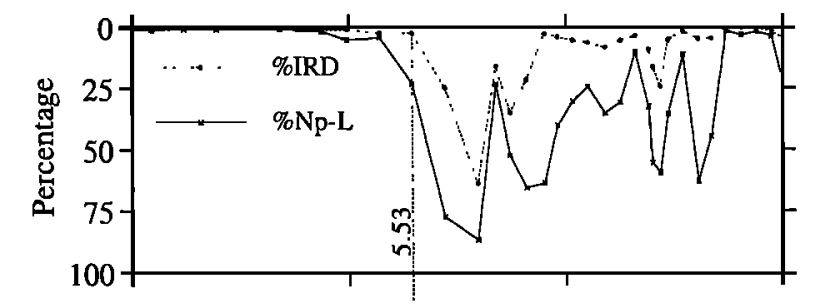

c)
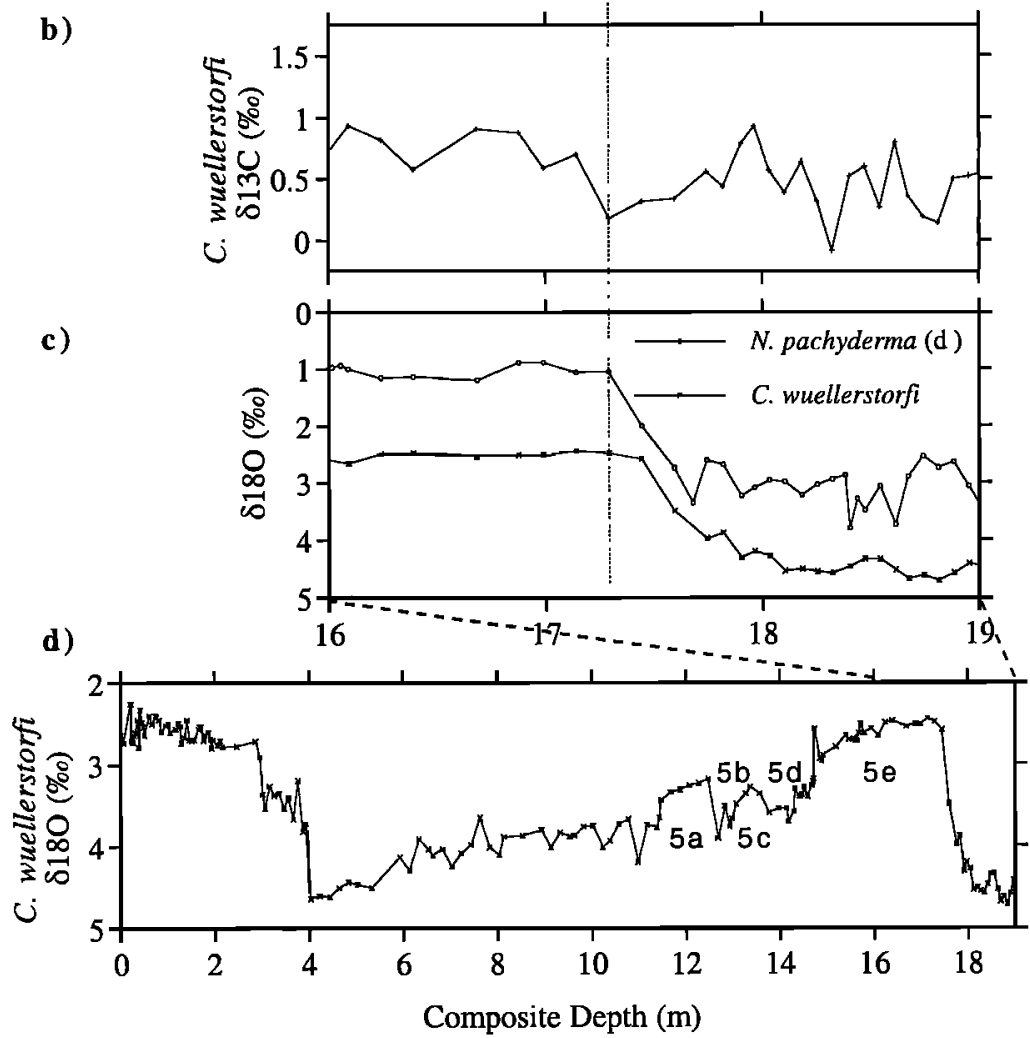

Figure 3. Records from site 980 versus depth. (a) Records of the percent ice-rafted detritus (IRD) and percent Neogloboquadrina pachyderma (sinistral) for Termination II and peak of substage 5e. (b) Benthic $\delta^{13} \mathrm{C}$ record for Termination II and peak of substage 5e. (c) Benthic and planktic $\delta^{18} \mathrm{O}$ records for Termination II and the peak of substage 5e. (d) Benthic $\delta^{18} \mathrm{O}$. MIS 5 substages are labeled. Depth assigned to the beginning of the peak of substage $5 e$ (event 5.53) is marked by vertical dotted line.

tution using standard techniques [Keigwin and Boyle, 1999; Ostermann and Curry, 2000]. Procedures for the NEAP18K record are outlined by Chapman and Shackleton [1999, and references therein].

\section{Results and Discussion}

Benthic and planktic $\delta^{18} \mathrm{O}$ stratigraphy for the subtropical sites and the detailed data for Termination II from subpolar North Atlantic site 980 and core 8JPC are shown versus depth in Figures 2-4 respectively. MIS 5 and its substages [Shackleton, 1969] are easily identified in the benthic $\delta^{18} \mathrm{O}$ records. We placed the records on a common timescale by correlating each benthic $\delta^{18} \mathrm{O}$ record to the orbitally-tuned chronology of Martinson et al. [1987],(Plate 1). This involved minor modification to the published NEAP18K time scale on the substage 5e/5d transition [Chapman and Shackleton, 1999].
At site 980 and core $8 \mathrm{JPC}$ the presence of IRD at levels that also contain the first low $-\delta^{18} \mathrm{O}$ values above MIS 6 indicates that these levels are deglacial in age (Figures 3 and 4). Without records of IRD these levels could be mistaken for the beginning of the substage $5 \mathrm{e}$ interval of minimum ice volume. We suggest $\delta^{18} O$ values are low at this time because of the subduction of low- $\delta^{18} \mathrm{O}$ deglacial meltwater [Lehman et al., 1993; Raymo et al., 1998]. We thus used the benthic $\delta^{18} \mathrm{O}$ and IRD records to refine the $\delta^{18} \mathrm{O}$-based chronology in the following manner. For core 8JPC we assign the first low IRD (6\%), low benthic $\delta^{18} \mathrm{O}$ level at $1154.25 \mathrm{~cm}$ to the beginning of peak interglacial substage 5e (event 5.53 [Martinson et al., 1987]). Similarly, for site 980 we assign the first low IRD (6\%), low benthic $\delta^{18} \mathrm{O}$ level at $17.29 \mathrm{~m}$ to event 5.53 . We further assumed that within substages 5a-5d the percent $N$. pachyderma (s.) at site 980 could not exceed the percent $N$. pachyderma (s.) at the colder, more northerly site of 


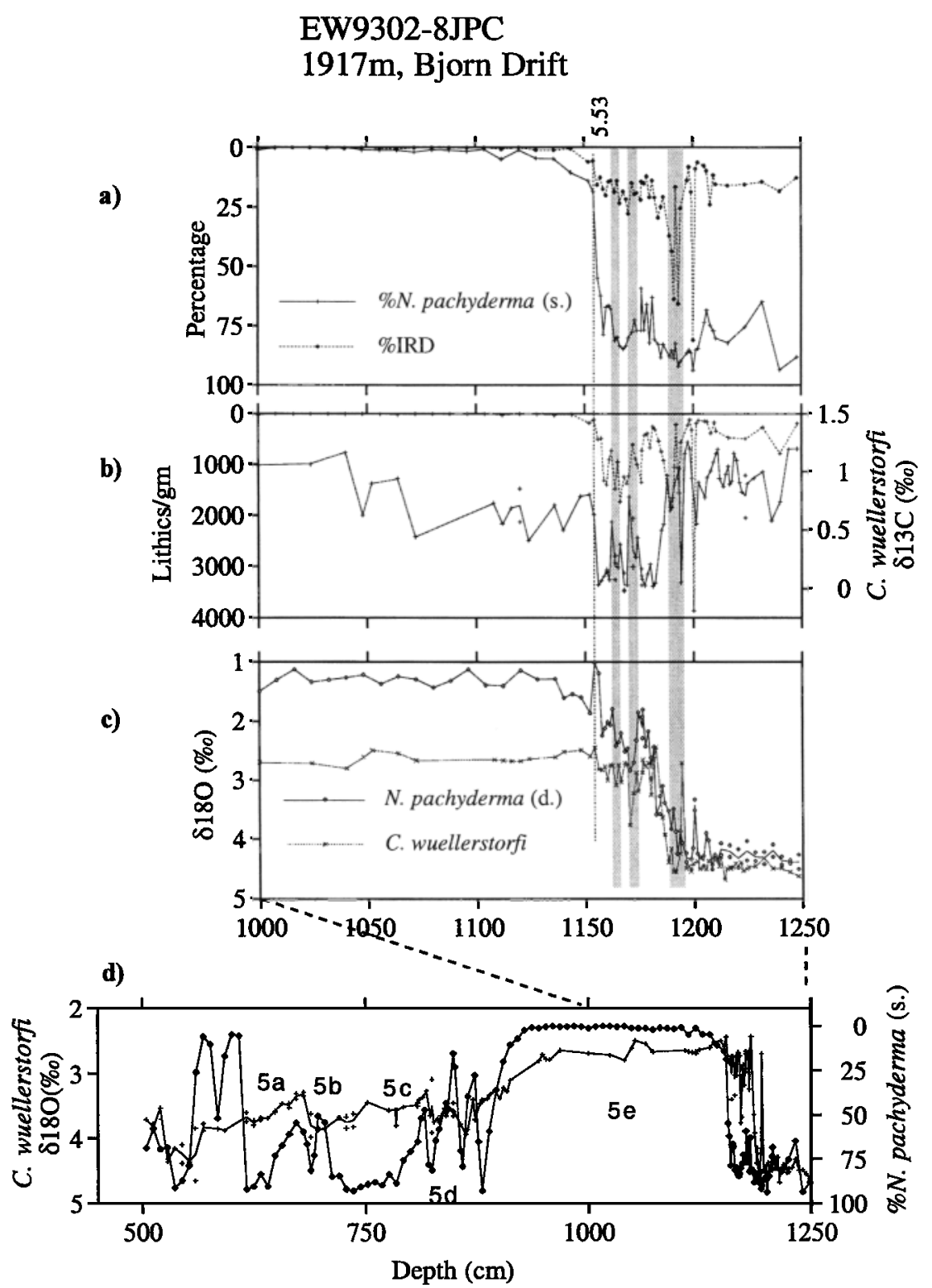

Figure 4. Records from core 8JPC versus depth. (a) Records of the percent IRD and percent $N$. pachyderma (s.) for Termination II and peak of substage $5 e$. (b) Benthic $\delta^{13} \mathrm{C}$ (solid line) and number of lithics per gram (dotted line) for Termination II and peak of substage 5e. (c) Benthic and planktic $\delta^{18} \mathrm{O}$ records for Termination II and the peak of substage Se. (d) Benthic $\delta^{18} \mathrm{O}$ record (crosses) and percent $N$. pachyderma (s.) (solid diamonds) for MIS 5. MIS 5 substages are labeled. Depth assigned to the beginning of the peak of substage $5 \mathrm{e}$ (event 5.53 ) is marked by vertical dotted line. Deglacial high- $\delta^{13} \mathrm{C}$ events are shaded to aid visual comparison among the records.

core 8JPC (Plate 1). This SST gradient is expected from the modern hydrography, and even more so for colder times when the gradient between these regions was greater [e.g., Climate: Long-Range Investigation, Mapping, and Prediction (CLIMAP), 1976, 1981]. This procedure involved only minor modification of the preliminary $\delta^{18} \mathrm{O} /$ IRD-based chronology of core 8JPC (not shown).

The $G$. ruber $\delta^{18} \mathrm{O}$ records from the two subtropical sites are similar, showing well-developed 4-10 kyr cycles that must represent a regional signal (Figure 2). However, because of the greater accumulation rates at site $1059(20 \mathrm{~cm} / \mathrm{kyr})$ than at core $37 \mathrm{JPC}(8 \mathrm{~cm} / \mathrm{kyr})$ the shorter oscillations ( $<3 \mathrm{kyr}$ ) are resolved better at site 1059 . Thus, in the following discussions of variability in this region we focus on results from site $\mathbf{1 0 5 9}$ and compare the records from this site to records from the subpolar North Atlantic (Plate 1). During the MIS 5 interval, sedimentation rates average $\sim 10,7$, and $11 \mathrm{~cm} / \mathrm{kyr}$ at the sites of 8JPC, V29-191, and 980, respectively.

\subsection{MIS 5}

Many studies have explored climate variations during MIS 5. The stability of the peak of MIS 5, substage $5 \mathrm{e}$, has been the subject of some controversy. Marine and terrestrial records from the North Atlantic and surrounding regions have been interpreted to indicate that the climate of substage 5e was stable [e.g., Bauch et al., 1996; 


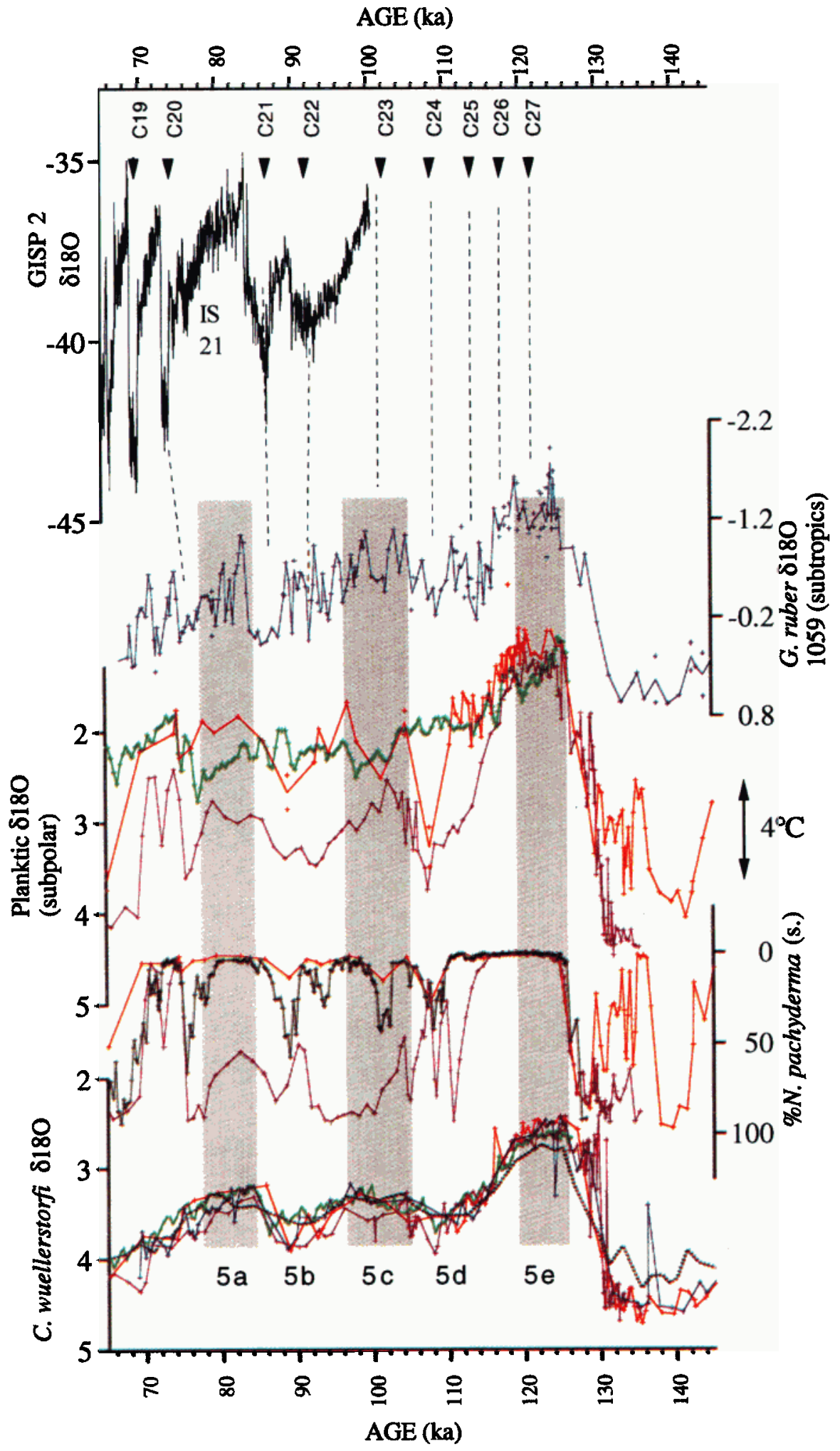

Plate 1. Records from core 8JPC (purple), 980 (red), 1059 (blue), and NEAP18K (green) versus age. From top to bottom; the $\delta^{18} \mathrm{O}$ record from GISP 2 [Grootes et al., 1993; Grootes and Stuiver, 1997; Meese et al., 1994, Stuiver et al., 1995; Stuiver and Grootes, 2000 ] with cold stadials are labeled, planktic $\delta^{18} \mathrm{O}$ record from site 1059 , planktic $\delta^{18} \mathrm{O}$ records from site 980 , core $8 \mathrm{JPC}$ and NEAP18K [Chapman and Shackleton, 1999], $N$. pachyderma (s.) percentage records from site 980 (red), 8JPC (purple) and core V29-191 (black [McManus et al., 1994]), and benthic $\delta^{18} \mathrm{O}$ records with the benthic $\delta^{18} \mathrm{O}$ stack (black) from Martinson et al. [1987]. Interglacial substages are shaded. Records of the percentage of $N$. pachyderma (s.) and of $\delta^{18} \mathrm{O}$ of planktonic foraminfera are scaled to equivalent temperature change assuming the full range of $N$. pachyderma (s.) corresponds to $8^{\circ} \mathrm{C}$ [Kohfeld et al., 1996] and an increase in $\delta^{18} \mathrm{O}$ of $0.23 \%$ for a $1^{\circ} \mathrm{C}$ cooling. 
McManus et al., 1994; Oppo et al., 1997; Woillard, 1978] or unstable [Dansgaard et al., 1993; Tzedakis, 1993; Thouveny et al., 1994; Field et al., 1994, Cortijo et al., 1994; Fronval and Jansen, 1996, 1997; Maslin et al., 1996; Seidenkrantz and Knudsen, 1997; Seidenkrantz et al., 1995; Sejrup et al., 1995]. There is, however, widespread agreement that abrupt events spaced -4-10 kyr apart (labeled C19 through C25 on Plate 1) and recorded in marine [e.g., Keigwin et al., 1994; McManus et al., 1994; Fronval and Jansen, 1997; Oppo et al., 1997] and terrestrial [Woillard, 1978; Thouveny et al., 1994; An and Porter, 1997] sequences and in ice cores [Grootes et al., 1993] throughout the remainder of MIS 5 (substages 5a-5d) are approximately contemporaneous.

The new planktic $\delta^{18} \mathrm{O}$ records from site 1059 and JPC37 on the Blake Outer Ridge (Figure 2 and Plate 1) increase the spatial extent of apparently synchronous 4-10 kyr scale climate oscillations during MIS 5 to include the western subtropical Atlantic. In addition, the site 1059 record suggests variability on this timescale also within the peak of substage 5e. We label the youngest of these events C26 [after Chapman and Shackleton, 1999], and suggest that other related events preceded it (C27-C29) (Figure 2 and Plate 1). Somewhat muted expressions of these events may also exist in the subpolar North Atlantic planktic $\delta^{18} \mathrm{O}$ records (Plate 1). Furthermore, shorter cycles (1-4 kyr) appear to characterize all of MIS 5 in the subtropical planktic $\delta^{18} \mathrm{O}$ record.

To examine the nature of suborbital variability within MIS 5 more closely, we estimated the power spectrum of the site $1059 \mathrm{G}$. ruber $\delta^{18} \mathrm{O}$ record using multitaper methods [Thomson, 1990] (Figure 5). Spectral peaks occur in a broad band between 4.8 and $12 \mathrm{kyr}$ (maximum power at 6 and $10 \mathrm{kyr}$ ), near 4.4 and $3.25 \mathrm{kyr}$, and at several frequencies corresponding to periods $<2.7 \mathrm{kyr}$ (e.g., 2.4, 2.0, and others). These results compare favorably to the results of Chapman and Shackleton [1999] for NEAP18K, although these authors did not discuss variations shorter than $3 \mathrm{kyr}$. They are also equivalent to the cycles found in this region during MIS 3 [Keigwin and Jones, 1994].

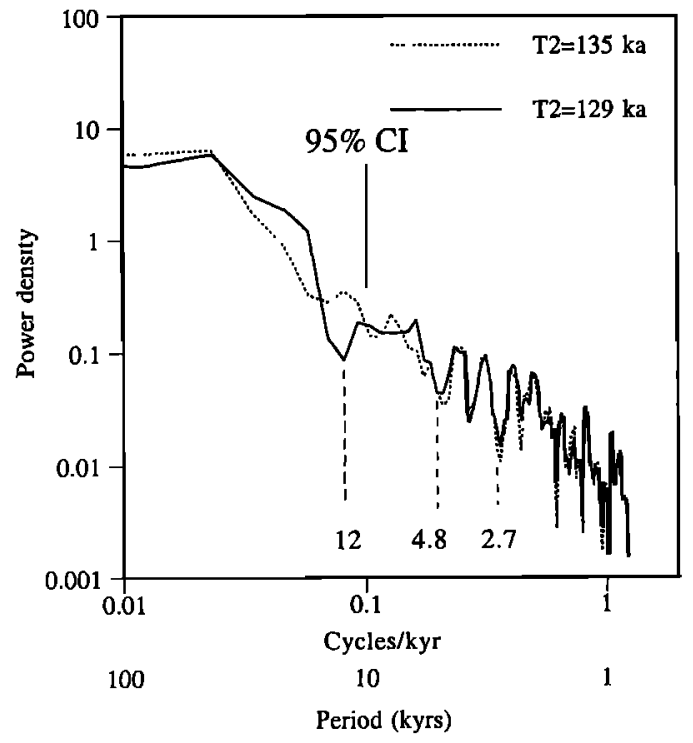

Figure 5. Power spectrum of the site $1059 G$. ruber $\delta^{18} \mathrm{O}$ record for the original timescale (solid line) and revised timescale (dashed line). Vertical dashed lines denote the cutoff periods used for the filtered records in Figure 6. Power spectrum was estimated using multitaper methods [Thomson, 1990].

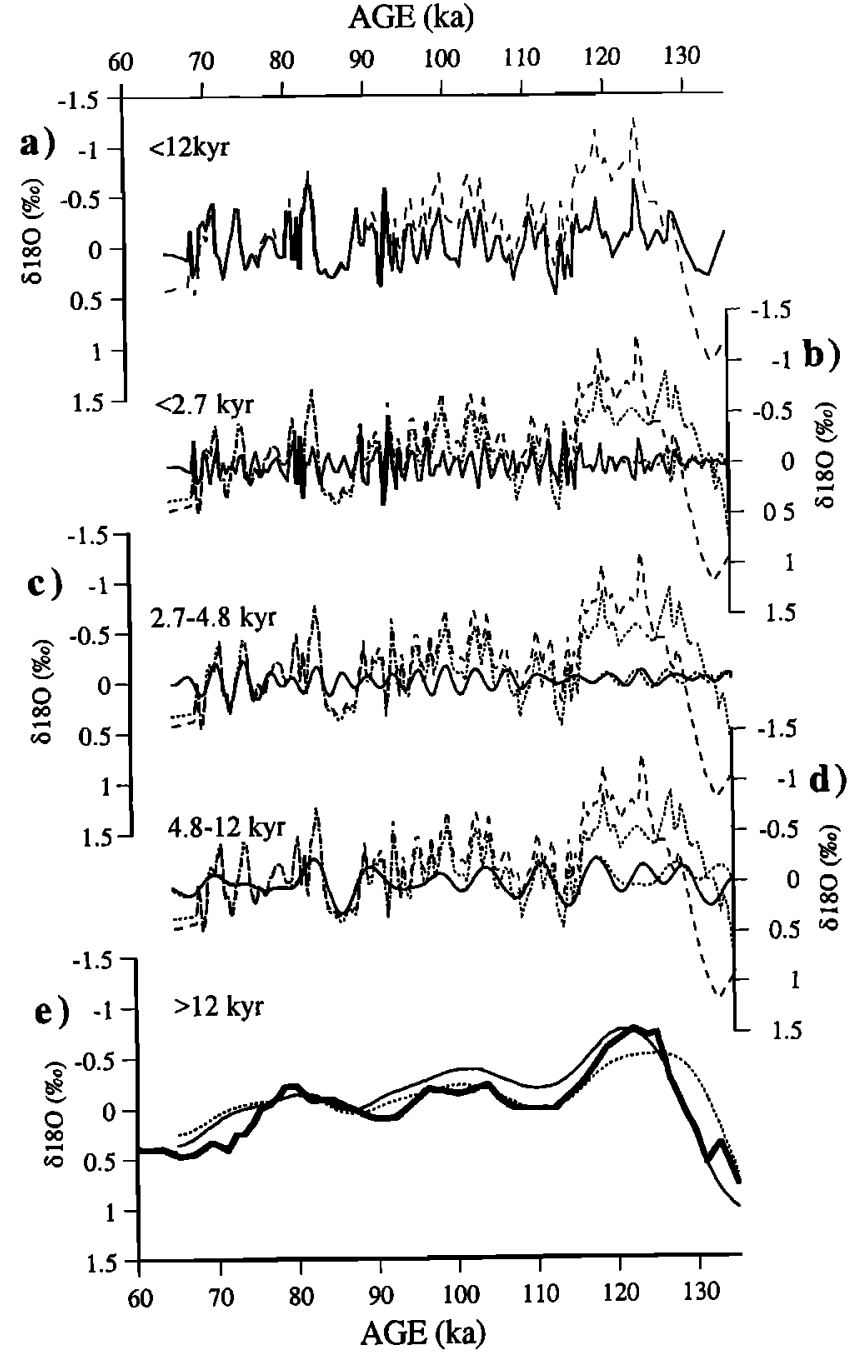

Figure 6. Site 1059 G. ruber $\delta^{18} \mathrm{O}$ records. (a-d) Variability at denoted periods (solid lines) compared to detrended original data (dashed lines). For Figures $6 \mathrm{~b}-6 \mathrm{~d}$, results for the original timescale (solid lines) and older Termination II (dotted lines) are both shown. (e) Variability at periods $>12 \mathrm{kyr}$ (original timescale; thin solid line) and $>14 \mathrm{kyr}$ (revised timescale; dotted line) compared to the benthic $\delta^{18} \mathrm{O}$ stack of Martinson et al. [1987] (thick line).

To examine whether temporal changes occurred in the amplitude of suborbital oscillations during MIS 5, we high-pass filtered the G. ruber $\delta^{18} \mathrm{O}$ record (periods shorter than $12 \mathrm{kyr}$ ). The results show that the amplitude of suborbital variations $(-0.5-0.7 \%)$ is approximately constant for the whole of MIS 5 , including substage $5 \mathrm{e}$ (Figure 6a). To assess if there were significant variations in the frequency of suborbital variability within MIS 5, we also used three narrower-band filters (Figures 6b-6d). Because our age control is limited by the orbital chronology, the accuracy of the suborbital periods provided by the spectrum may be poor. Thus we applied relatively broad band filters to the record and acknowledge that some power present in one band may actually belong in another. Our results suggest that $\delta^{18} \mathrm{O}$ variations in the three bands $(-4.8-12$, $2.7-4.8$, and $<2.7 \mathrm{kyr}$ ) persist throughout MIS 5. It is apparent that variations in each of these bands contribute to the high amplitude of the suborbital oscillations (Figures 6b-6d). As expected, the residual variability (>12 kyr) closely follows the global $\delta^{18} \mathrm{O}$ stack [Martin- 
son et al., 1987] (Figure 6e), which has a large ice volume component [Shackleton, 1969].

The age of Termination II is currently under vigorous debate [e.g., Karner and Muller, 2000]. Placing the midpoint of the deglaciation at $135 \mathrm{ka}$ [e.g., Henderson and Slowey, 1999] lengthens substage $5 \mathrm{e}$ but does not affect our results significantly (Figures 5 and 6 ). The broad band of power between 5 and $12 \mathrm{kyr}$ (maximum power at $\sim 6$ and $10 \mathrm{kyr}$ ) is further broadened to include periods up to $-14 \mathrm{kyr}$ (maximum power at $\sim 8$ and $12 \mathrm{kyr}$ ). The shape of the spectrum at higher frequencies is almost unchanged. In terms of the filtered records, the changes are minor, although with an older Termination II, there are fewer well-developed cycles in the higher-frequency band (periods $<2.7 \mathrm{kyr}$ ) within the peak of substage $5 \mathrm{e}$.

If the $\sim 0.5-0.7 \%{ }^{18} \mathrm{O}$ suborbital oscillations are entirely driven by SST changes, they correspond to oscillations of $\sim 2^{\circ}-3^{\circ} \mathrm{C}$. This is comparable to amplitude of MIS 3 oscillations at sites located $\sim 2^{\circ}-3^{\circ}$ south of site 1059 and smaller than those estimated at the Bermuda Rise $\left(3^{\circ}-5^{\circ} \mathrm{C}\right)$ [Sachs and Lehman, 1999]. Given that planktic $\delta^{18} \mathrm{O}$ variations in the region during MIS 3 were the results of SST changes [Keigwin and Boyle, 1999; Sachs and Lehman, 1999], this is the simplest explanation for the planktic $\delta^{18} \mathrm{O}$ oscillations at these subtropical sites during MIS 5.

Although SST variability is our preferred interpretation of the planktic $\delta^{18} \mathrm{O}$ oscillations, it remains to be proven for MIS 5 , and other possibilites exist. For example, a recent study suggests that orbitally driven changes in the meridional gradient of mean annual insolation control SST and sea surface salinity (SSS) trends during substage 5e at subtropical and subpolar latitudes [Cortijo et al., 1999]. In their study, Cortijo et al. [1999] implicitly attributed the apparent suborbital variability in planktic $\delta^{18} \mathrm{O}$ within substage 5e in the subpolar North Atlantic to the opposing influence of orbitally forced linear trends in SST and SSS. While this may indeed be the case, our results from the subtropics suggest that the suborbital variations within substage $5 \mathrm{e}$ are related to a persistent series of oscillations. Thus we suggest that it is unlikely that a linear combination of orbital-scale SSS and SST changes can explain the clear evidence of suborbital-scale variability within substage $5 \mathrm{e}$.

Our results suggest that suborbital variations in the western subtropical North Atlantic during MIS 5 were similar in magnitude and timing to those which occurred in this region during MIS 3 [e.g., Keigwin and Boyle, 1999; S. Hagen and L.D. Keigwin, Sea surface temperature variability and deep water reorganizations in the subtropical North Atlantic during isotope Stage 2-4, submitted to $\mathrm{Ma}$ rine Geology, 2000]. To our knowledge, persistent, high-amplitude suborbital climate cycles of $3 \mathrm{kyr}$ duration or less have not been observed in other records of MIS 5 . However, one clue that this variability is not only real but also not restricted to this location comes from the Greenland ice cores. During substages $5 a$ and $5 b$, each of the 1-3 kyr oscillations in the subtropical records appears to have a subtle equivalent in the unsmoothed Greenland Ice Sheet Project 2 (GISP 2) ice core $\delta^{18} \mathrm{O}$ record [Grootes et al., 1993; Grootes and Stuiver, 1997; Meese et al., 1994, Stuiver et al., 1995; Stuiver and Grootes, 2000] (Plate 1).

Additional evidence that these variations have a counterpart in the North Atlantic comes from a detailed study of variations in different types of lithic grains [Bond et al., 1999]. Bond et al. show that a 1-2 kyr cycle in the percentage of hematite-stained grains spans the entire interval from the Holocene through the latter half of substage 5a. These grains probably derived from red beds in east Greenland, Svalbaard, or the Arctic Ocean and suggest millennial- scale changes in North Atlantic surface circulation during the latter half of substage 5a. At present, there are few marine records that are adequate to assess whether correlative SST variations occurred in the subpolar North Atlantic. Published records either do not have the temporal resolution (e.g., 8JPC and 980 records shown in Plate 1) or they utilize percent $N$. pachyderma (s.), which cannot capture the full range of SST variability beyond certain SST limits (e.g., V29191 of McManus et al. [1994]). Although adequately resolved, the NEAP18K $\delta^{18} \mathrm{O}$ record of the planktic foraminifera Globigerina bulloides does not exhibit variability of comparable frequency and amplitude throughout MIS 5 (Plate 1). This may be because $G$. bulloides do not always faithfully record surface water variations in this region or because these variations did not occur at this site. However, the finding of apparently contemporaneous temperature oscillations in the ice core and subtropical surface records during substage 5a suggests that they are at least regional in extent. We predict that comparable variability will be found in the subpolar North Atlantic throughout MIS 5.

In contrast to results from North Atlantic records, which suggest that high-amplitude suborbital variability occurs when a modest ice volume threshold is crossed (equivalent to a lowering of sea level by $30 \mathrm{~m}$ [McManus et al., 1999], $40 \mathrm{~m}$ [Chapman and Shackleton, 1999], and $45 \mathrm{~m}$ [Schulz et al., 1999]), our results suggest that there is no ice volume threshold for high-amplitude suborbital variability in the subtropical western Atlantic. Factors in addition to ice volume must be important in setting the stage for suborbital variability in the subtropics.

For example, latitudinal temperature gradients may respond rapidly to changing insolation and drive changes in large-scale wind fields with far-reaching influences. Such influences may include changes in regional evaporation/precipitation patterns, in the strength, physical properties, and/or position of the Gulf Stream and other important boundary currents, and under certain conditions, in temperature and salinity in areas of deepwater production. Exactly why or how any of these changes would set a millennial oscillator in motion remains unclear. Recent modeling efforts have focused on the possibility of millennial oscillations of the El Niño-Southem Ocsillation (ENSO) cycle [e.g. Clement and Cane, 1999; Cane and Clement, 1999]. Although ENSO is largely a tropical Pacific phenomenon, it appears to have an almost global influence. Modeling also suggests that tropical surface salinity anomalies caused by millennial oscillations in the ENSO cycle could impact deepwater formation in the North Atlantic region [Schmittner et al., 2000].

The occurrence of the same variability at locations near the axis of the Gulf Stream and in the subpolar North Atlantic suggests that variations in thermohaline circulation, which redistributes heat, may play be important for transmitting or amplifying suborbital climate variability. There is some evidence for a link between longer suborbital ( $(-10 \mathrm{kyr})$ variability and deep circulation during MIS 5 on the basis of studies of the benthic $\delta^{13} \mathrm{C}$ proxy for nutrient content [Chapman and Shackleton, 1999; Keigwin et al., 1994].

At site 1059 we were unable to produce a high-resolution benthic $\delta^{13} \mathrm{C}$ record because the abundance of $C$. wuellerstorfi and other suitable benthic foraminifera was lowered by terrigenous dilution. However, nearly synchronous benthic $\delta^{13} \mathrm{C}$ and planktic $\delta^{18} \mathrm{O}$ oscillations at site 1059 provide evidence of a surface-deepwater linkage early in substage 5e (Plate 2; hatched intervals). The benthic $\delta^{13} \mathrm{C}$ record from core 37JPC is more complete (Figure 2). As is true of other benthic $\delta^{13} \mathrm{C}$ records from this region [Keigwin et al., 1994], 4-10 kyr variability is evident, with episodes of weak NADW (low 


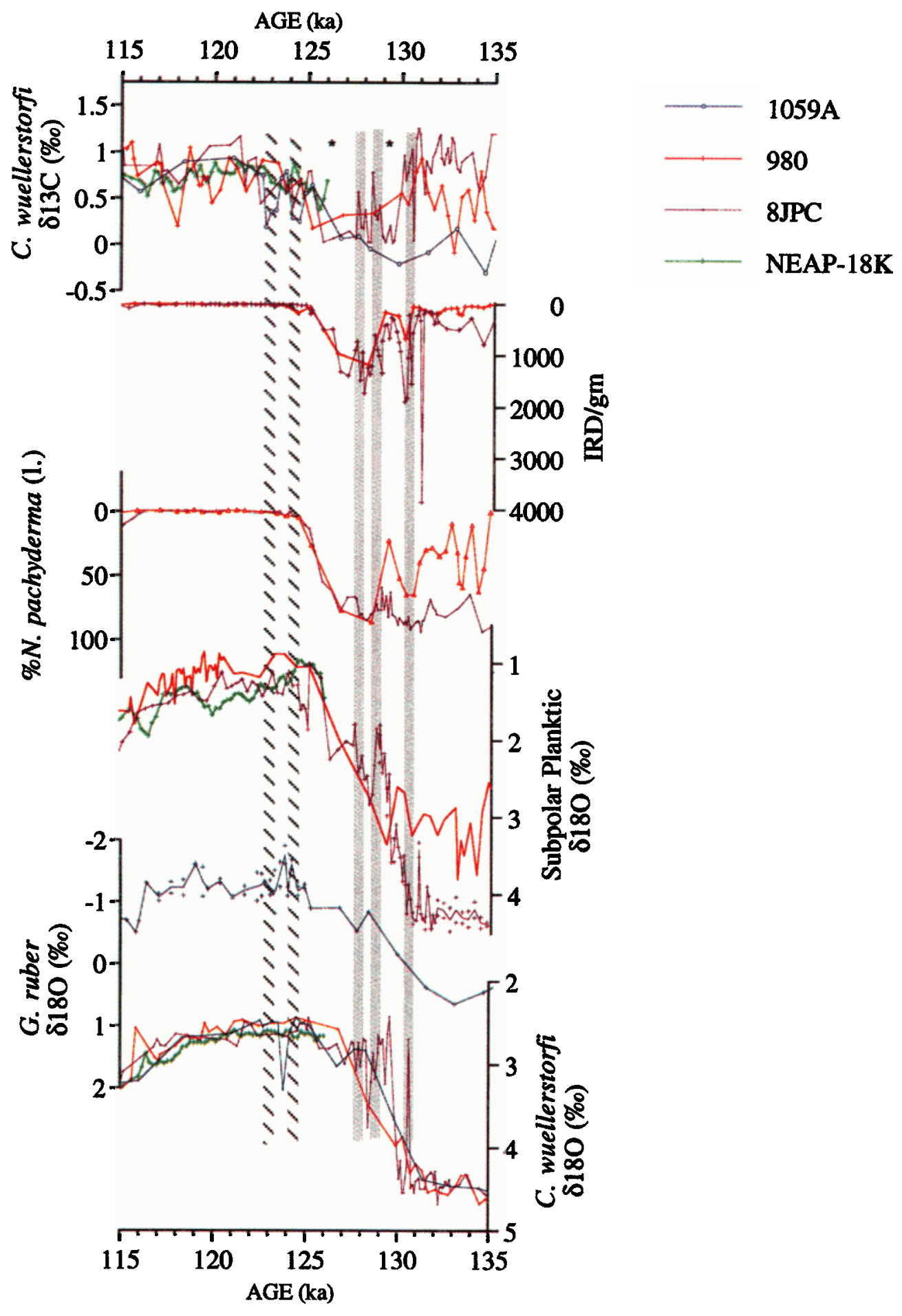

Plate 2. Records from core 8JPC (purple), 980 (red), 1059 (blue), and NEAP18K (green) for the deglaciation and substage 5e. From top to bottom; benthic $\delta^{13} \mathrm{C}$ records, IRD (lithic per gram) records from site 980 and $8 \mathrm{JPC}, N$. pachyderma (s.) percentage records from site 980 and $8 \mathrm{JPC}$, planktic $\delta^{18} \mathrm{O}$ records from site 980 , core $8 \mathrm{JPC}$, and $\mathrm{NEAP} 18 \mathrm{~K}$, planktic $\delta^{18} \mathrm{O}$ record from site 1059 , and benthic $\delta^{18} \mathrm{O}$ records. Shaded and hatched intervals are discussed in text. Asterisks denote the deglacial benthic $\delta^{13} \mathrm{C}$ minima discussed in text. 
benthic $\delta^{13} \mathrm{C}$ values) associated with planktic $\delta^{18} \mathrm{O}$ evidence for surface cooling (Figure 2). However, this and other records are not adequately resolved to assess whether the $1-3 \mathrm{kyr}$ timescales variations that persist through MIS 5 are associated with changes in NADW.

\subsection{Termination II}

The subpolar North Atlantic records show clear evidence of surface oscillations during the MIS $6 / 5$ transition (Plate 2). At the northwesterly site of core 8JPC our earlier study indicated that SST remained cool throughout the deglaciation [Oppo et al., 1997]. The higher-resolution data showing that percent $N$. pachyderma (s.) alternated between -75 and $100 \%$ confirm this conclusion but also reveal two well-defined, modest (10-15\% range) percent $N$. pachyderma (s.) oscillations superimposed on an overall $25 \%$ decrease $\left(-2^{\circ} \mathrm{C}\right.$ warming) that began at the onset of deglaciation (Plate 2$)$. At southeasterly site 980 , dramatic percent $N$. pachyderma (s.) (SST) oscillations that occurred during the deglaciation $(17-18 \mathrm{~m})$ (Figure 3) cannot be distinguished from those that occurred earlier during glacial times.

At site 980 (2179 $\mathrm{m}$ water depth) a benthic $\delta^{13} \mathrm{C}$ minimum persists through Termination II, consistent with earlier observations from core 8JPC [Oppo et al., 1997] and other North Atlantic sites (Adkins et al. [1997] (Cd/Ca data) and Sarnthein and Tiedemann [1990]). The detailed data from core 8JPC provide a more complete history of deepwater circulation and variability during the deglaciation (Figure 4 and Plate 2). Relatively high benthic $\delta^{13} \mathrm{C}$ values $(-1 \% \circ)$ at core $8 \mathrm{JPC}$ indicate vigorous GNAIW production during an early deglacial ice rafting event (shaded interval near $-130 \mathrm{ka}$ ). Lithic and faunal evidence suggest that an episode of IRD reduction and warming followed this event. This warm episode was associated with planktic and benthic $\delta^{18} \mathrm{O}$ evidence for ice sheet melting as well as low $\delta^{13} \mathrm{C}$ values. The percent $N$. pachyderma (s.) data and published faunal SST estimates from $8 \mathrm{JPC}$ suggest a $2^{\circ} \mathrm{C}$ rise at this time [Oppo et al., 1997] equivalent to $\sim 0.5 \%$ decrease in $\delta^{18} \mathrm{O}$. Even assuming the most extreme case that $1 \%$ of the total planktic $\delta^{18} \mathrm{O}$ decrease since the onset of deglaciation $(2.5 \%$ ) was related to early sea level rise, a full $1.0 \%$ of the planktic $\delta^{18} \mathrm{O}$ rise must be explained by pooling of fresh water at the surface during this relatively warm, low- $\delta^{13} \mathrm{C}$ event. High benthic $\delta^{13} \mathrm{C}$ values follow this event (shaded intervals) and are associated with lithic evidence of moderate ice rafting. Benthic $\delta^{13} \mathrm{C}$ values return to low values following these events. Unlike the earlier low- $\delta{ }^{13} \mathrm{C}$ event, lithic evidence suggests significant ice rafting during the earlier part of the second of the two significant low $-\delta^{13} \mathrm{C}$ events (marked by asterisks on Plate 2). Later in the second event, just prior to the end of the deglaciation, surface waters warmed, and IRD delivery decreased rapidly, and planktic $\delta^{18} \mathrm{O}$ suggests significant meltwater delivery.

Thus the data from 8JPC clearly demonstrate the occurrence of millennial-scale variations in SST, delivery of ice-rafted material, and intermediate-water $\delta^{13} \mathrm{C}$ during the penultimate deglaciation. In order to evaluate the significance of these oscillations, it is useful to examine published data from Norwegian Sea site 644 (1227 m) [Fronval and Jansen, 1997] (Figure 7). If we assume that the end of the deglaciation was marked by nearly IRD-free sediments, then the first two warm events as denoted by low percent $N$. pachyderma (s.) occurred within the deglaciation. Each of these warm events was accompanied by low benthic $\delta^{13} \mathrm{C}$ values. If these two low- $\delta^{13} \mathrm{C}$ events are coeval with the longer of the three deglacial low- $\delta^{13} \mathrm{C}$ events at site $8 \mathrm{JPC}$ (events marked by asterisks on Plate 2 ), then one

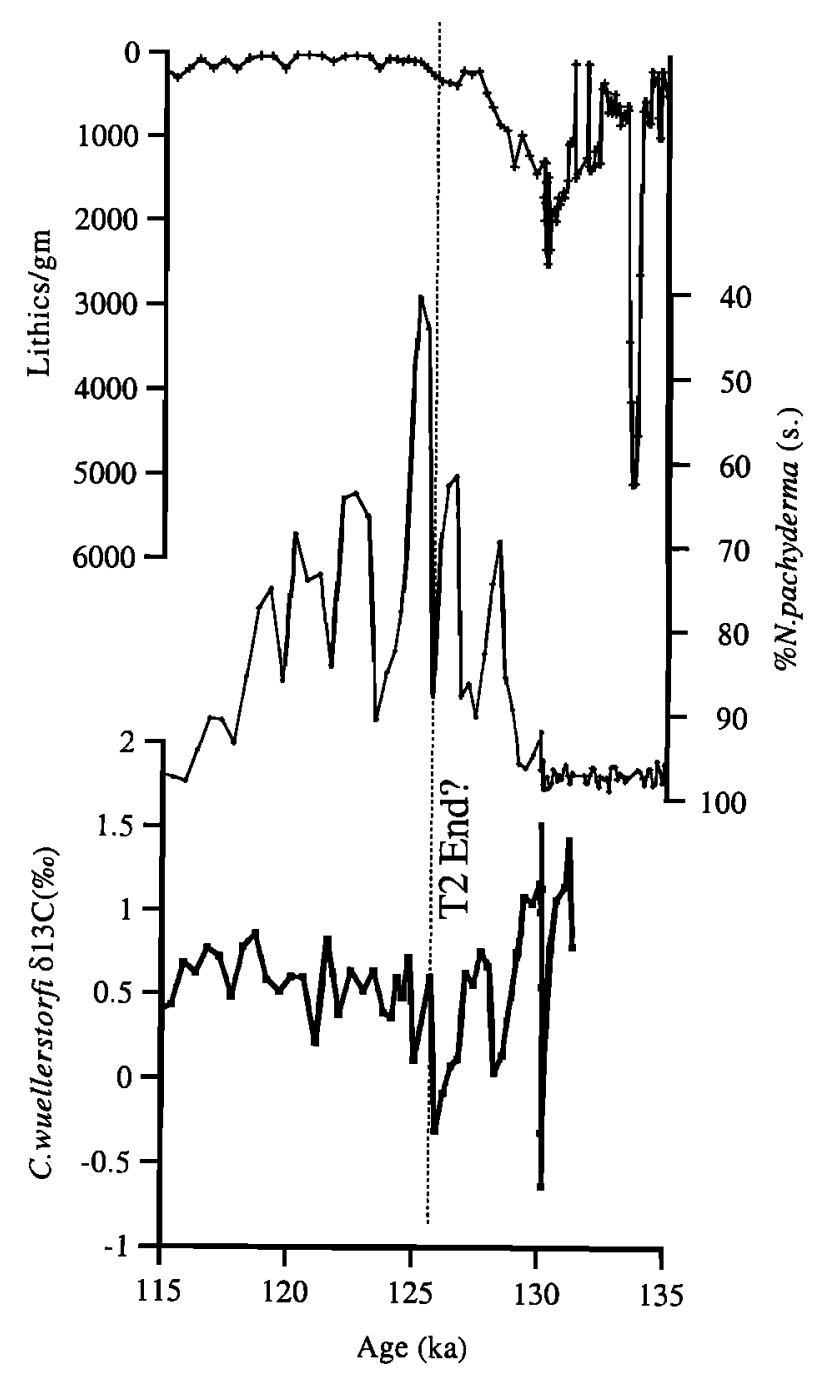

Figure 7. Records from site 644 [ Fronval and Jansen, 1997]. From top to bottom; number of lithics per gram dry bulk sediment, percent $N$. pachyderma (s.), and benthic $\delta^{13} \mathrm{C}$. If the vertical line marks the end of the deglaciation, then the two preceding $\delta^{13} \mathrm{C}$ minima may be correlative with deglacial $\delta^{13} \mathrm{C}$ minima at core 8JPC (Plate 2).

may consider the possibility that the low $-\delta^{13} \mathrm{C}$ water originated in the Nordic Seas [Bauch et al., 2000]. The association of low $-\delta^{13} \mathrm{C}$ values with warmth suggests that warm, low-latitude surface and thermocline waters penttrated into the Norwegian Sea during these events. During the first of the two low $-\delta^{13} \mathrm{C}$ events, low planktic $\delta^{18} \mathrm{O}$ values in the subpolar North Atlantic suggest that the atmospheric heat release was sufficient to cause rapid deglacial melting, as discussed above. Lithic, faunal, and planktic $\delta^{18} \mathrm{O}$ evidence also suggests that warming and deglacial melting occurred in the latter portion of the second low- $\delta^{13} \mathrm{C}$ episode.

If inflow to the Nordic Seas during the two low- $\delta^{13} \mathrm{C}$ events was via the upper ocean, then it is likely that overflow waters exited the Nordic Seas as they do today and influenced the nutrient chemistry of the open North Atlantic. A bathymetric $\delta^{13} \mathrm{C}$ transect reconstructed from cores south of the ridges suggests that this low $-\delta^{13} \mathrm{C}$ water influenced the depth range between 1500 and $2000 \mathrm{~m}$ but may have been less of an influence in deeper waters [Oppo et al., 1997]. This 
apparent restriction to intermediate depths may indicate that overflow waters were less dense than today because of the strong influence of surface meltwater.

Under this scenario, during warm deglacial episodes, low $-\delta^{13} \mathrm{C}$ waters exited the Nordic Seas as overflow water and bathed the intermediate-depth North Atlantic. During cold deglacial episodes, high $-\delta^{13} \mathrm{C}$ waters were produced south of the sills in a manner akin to that envisioned for the Last Glacial Maximum [e.g., Boyle and Keigwin, 1987; Labeyrie et al., 1992]. This is our preferred scenario.

However, if the proposed correlation of the $\delta^{13} \mathrm{C}$ events at site 644 and core $8 \mathrm{JPC}$ is correct, then $\delta^{13} \mathrm{C}$ values across the entire deglaciation were similar at the two sites, suggesting the possibility of continuous communication between the Nordic Seas and the middepth North Atlantic. Thus the Nordic Seas may have been the source of North Atlantic intermediate waters throughout the deglaciation. This constant-source scenario is less appealing because it raises the related questions of why $\delta^{13} \mathrm{C}$ values varied and why surface waters remained cold during intervals when high- $\delta^{13} \mathrm{C}$ surface and thermocline waters entered the Norwegian Sea. It is possible that $\delta^{13} \mathrm{C}$ variations reflect variations in isotopic exchange with the atmosphere, which varies both as a function of SST and wind stress [Mook et al., 1974; Liss and Merlivat, 1986]. Perhaps during high $-\delta^{13} \mathrm{C}$ episodes, heat associated with upper ocean inflow was channeled into the melting of sea 1ce, leaving the surface cold, while setting the stage for the subsequent episodes of ice sheet melting. Clearly, additional work is needed to test these hypotheses and the alternate interpretation that low deglacial $\delta^{13} \mathrm{C}$ values reflect the complete absence of deepwater formation in the North Atlantic [Venz et al., 1999]. Knowing which scenario is correct has important implications for our interpretations of benthic $\delta^{13} \mathrm{C}$ records from open Atlantic sites.

This work confirms that deepwater geometry varied during Termination II [Rasmussen et al. 1999; Lototskaya and Ganssen, 1999] and further demonstrates significant SST oscillations in the eastem subpolar North Atlantic. Previous investigations failed to find multiple, large, Younger Dryas equivalent SST oscillations during Termination II for two reasons. First, high-resolution studies of the penultimate deglaciation used cores from northwesterly locations, such as 8JPC, where SST remained relatively cold throughout the deglaciation [e.g., Oppo et al., 1997], or from more southerly regions that were not affected by the first cold event [Chapman and Shackleton, 1998; Cortijo et al., 1999]. Second, studies of sediments from the more sensitive region near Feni Drift were undertaken in cores that did not penetrate the full deglaciation [McManus et al., 1994], or the records were not of sufficient resolution to resolve the oscillations [Ruddiman et al., 1980].

\section{Summary}

We found isotopic evidence of 5-10 kyr surface variability in the subtropics and in the subpolar North Atlantic during the peak of the last interglaciation, broadly known as substage 5e, suggesting that an ice volume threshold for high-amplitude variability on this timescale does not exist. The finding of persistent 1-3 kyr variability throughout MIS 5 provides additional support for claims that variations on this timescale occur in the absence of large ice sheets [e.g., Keigwin and Jones, 1989; O'Brien et al., 1995; Sirocko et al., 1996; Alley et al., 1997; Bond et al., 1997; Campbell et al., 1998; Bianchi and McCave, 1999]. Factors in addition to ice volume must be important for setting the stage for high-amplitude suborbital variability in the subtropics and perhaps also in the subpolar North Atlantic region through a response of the thermohaline circulation. Although there is evidence for a surface-deepwater link on 5-10 kyr timescales, published records are not detailed enough to assess whether such a link occurs on shorter ( $1-3 \mathrm{kyr}$ ) timescales. However, the evidence of coupled surface-deepwater oscillations during Terminations I [Keigwin et al., 1991; Lehman and Keigwin, 1992] and II (Figure 7 and Plate 2), provides strong support that ocean-ice interactions and deepwater variability amplifies suborbital variability [Broecker et al., 1990] and that the penetration of low-latitude surface waters into the Nordic Seas is an important factor for deglacial melting of ice sheets.

Acknowledgments. Thanks are due to the participants of Leg 172, Michael Horowitz for starting to process the Leg 172 material, and to Luping Zou, Martı Jeglinski, Rindy Ostermann, Susan Trimarchi, Ellen Roosen, Eben Franks, and to Stephanie Healey and other students in the Manne Geology Lab at Salem State College for technical assistance. We thank Ed Brook for discussions concerning the ice core data and Carl Wunsch for providing the software to carry out the multiple window spectral analysis. Discussions with Maureen Raymo, Bill Curry, and Giancarlo Bianchi are gratefully acknowledged Comments on the submitted manuscript by Henning Bauch and two anonymous reviewers were also very helpful. This work was funded by NSF grants OCE96-32372 (DWO and JFM), OCE92-17017 (LDK), and OCE95-10075 (LDK) and two JOI/USSAC grants (DWO and JLC) This is WHOI contrbution 10394

\section{References}

Adkins, J.F., E.A Boyle, L. Keigwin, and E. Cortijo, Variability of the North Atlantic thermohaline circulation duning the last interglacial period, Nature, 390, 154-156, 1997

Alley, R.B., P.A. Mayewski, T. Sowers, M Stuiver, K.C. Taylor, and P.U. Clark, Holocene climatic instability: A prominent, widespread event 8200 yг ago, Geology, 25, 483-486, 1997.

Alley, R.B., P.U. Clark, L.D. Keigwin, and R.S. Webb, Making sense of millennial-scale climate change, in Mechanisms of Global Climate Change at Millennial Time Scales, Geophys. Monogr. Sec, vol. 112, edited by P.U. Clark, R.S. Webb, and L.D. Keigwin, pp. 385-394, A. G. U, Washington, DC, 1999.

An, Z., and S.C. Porter, Millennial-scale climatic oscillations during the last interglaciation in central China, Geology, 25, 603-606, 1997.
Bauch, H.A., H Erlenkeuser, P.M. Grootes, and J. Jouzel, Implicatıons of stratigraphic and paleoclimatic records of the last interglaciation from the Nordic Seas, Quat. Res , 46, 260$269,1996$.

Bauch, H.A., H. Erlenkeuser, S.J A Jung, and J. Thiede, Surface and deep water changes in the subpolar North Atlantic during Termination II and the last interglaciation, Paleoceanography, 15, 76-84, 2000.

Bé, A.W.H, and D.S. Tolderlund, Distribution and ecology of living planktonic foraminifera in surface waters of the Atlantic and Indian Oceans, in Micropaleontology of Oceans, edited by B.M. Funnell and W.R. Riedel, pp 105-149, Cambridge Univ. Press, NY, 1971.

Bertram, C J., H. Elderfield, N.J. Shackleton, and J.A. MacDonald, Cadmium/calcium and carbon isotope changes of the glacial northeast
Atlantic, Paleoceanography, 10, 563-578, 1995.

Bianchi, G.G., and I.N. McCave, Holocene periodicity in North Atlantic climate and deepocean flow south of Iceland, Nature, 397, 515-517, 1999.

Bond, G., W. Broecker, S. Johnson, J. Jouzel, L. Labeyrie, J. McManus, and G. Bonani, Correlations between clımate records from North Atlantic sediments and Greenland ice, Nature, 365, 143-147, 1993.

Bond, G.C., et al., A pervasive cycle in North Atlantic Holocene and glacial sediments, Science, 278, 1257-1266, 1997.

Bond, G.C., et al., The North Atlantic's 1-2 kyr climate rhythm: Relation to Heinrich events, Dansgaard/Oeschger cylces and the Little Ice Age, in Mechanisms of Global Climate Change at Millennial Time Scales, Geophys. 
Monogr. Ser. vol. 112, edited by P.U. Clark, R.S. Webb, and L D. Keigwin, A. G. U., Washington, D. C., 1999.

Boyle, E.A , and L. Keigwin, North Atlantic thermohalıne circulation during the past 20,000 years linked to high-latitude surface temperature, Nature, 330, 35-40, 1987.

Broecker, W.S., and J.V. Donk, Insolation changes, ice volumes, and the 018 record in deep-sea cores, Rev Geophys 8, 169-198, 1970.

Broecker, W.S., G. Bond, and M. Klas, A salt oscillator in the Glacial Atlantic?, 1, The Concept, Paleoceanography, 5, 469-477, 1990.

Campbell, I.A., C. Campbell, M. Apps, N.W. Rutter, and A.B.G. Bush, Late Holocene -1500 yr climate penodicities and their implications, Geology, 26, 471-473, 1998.

Cane, M., and A.C Clement, A role for the tropical Pacific coupled ocean-atmosphere system on Milankovitch and millennial tumescales Part II: global impacts, in Mechanisms of Global Change at Millennial Time Scales, Geophy. Monogr. Ser. vol. 112, edited by P.U. Clark, R.S. Webb, and L.D. Keigwin, A. G U Washington, DC. 1999.

Chapman, M.R., and N.J. Shackleton, Global ice volume fluctuations, North Atlantic ice-rafting events, and deep-ocean circulation changes between 130 and $70 \mathrm{ka}$, Geology, 27, 795-798, 1999.

Clement, A.C., and M. Cane, A role for the tropical Pacific coupled ocean-atmosphere system on Milankovitch and millennial timescales Part I: a modeling study of tropical Pacific variability, in Mechanisms of Global Change at Millennial Time Scales, Geophy. Monogr. Ser. vol. 112, edited by P.U. Clark, R.S. Webb, and L.D. Keigwin, A. G. U. Washington, DC. 1999.

Climate: Long-Range Investigation, Mapping, and Prediction (CLIMAP), The surface of the ice-age Earth, Science, 191, 1131-1137, 1976.

Clımate: Long-Range Investigation, Mapping, and Prediction (CLIMAP), Seasonal reconstructions of the Earth's surface at the Last Glacial Maximum, Geol. Soc. Am. Map Chart Ser., $M C-36,1-18,1981$

Cortijo, E., J.C. Duplessy, L. Labeyrie, H.L. Leclaire, J. Duprat, and T.C.E. van Weering, Eemian cooling in the Norwegian Sea and North Atlantic ocean preceding continental ice-sheet growth, Nature, 372, 446-449, 1994.

Cortijo, E., S.J. Lehman, L. Keigwin, M. Chapman, D. Paillard, and L. Labeyrie, Changes in meridional temperature and salinity gradients in the North Atlantic Ocean $\left(30^{\circ} \mathrm{N}-72^{\circ} \mathrm{N}\right)$ during the last interglacial penod, Paleoceanography, 14, 23-33, 1999.

Dansgaard, W., S.J. Johnsen, H.B Clausen, and J. C. C. Langway, Climatic record revealed by the Camp Century ice core, in Late Cenozoic Glacial Ages, pp. 37-56, Yale Univ. Press, New Haven, CT, 1971

Dansgaard, W., et al., Evidence for general instability of past climate from a 250 -kyr ice-core record, Nature, 364, 218-220, 1993.

Duplessy, J.C., and N.J. Shackleton, Response of global deep-water circulation to Earth's climatic change $135,000-107,000$ years ago, Nature, 316, 500-507, 1985.

Field, M.H., B Huntley, and H. Miller, Eemian climate fluctuations observed in a European pollen record, Nature, 371, 779-783, 1994.
Fronval, T., and E. Jansen, Rapid changes in ocean circulation and heat flux in the Nordic Seas during the last interglacial period, Nature, 383, 806-810, 1996.

Fronval, T., and E. Jansen, Eemian and early Weichselian (140-60 ka) paleoceanography and paleoclimate in the Nordic seas with conparisons to Holocene conditions, Paleoceanography, 12, 443-462, 1997.

Grootes, P.M., and M. Stuiver, Oxygen 18/16 variability in Greenland snow and ice with $10^{3}$ to $10^{5}$-year resolution, J. Geophys Res., 102, 26,455-26,470, 1997.

Grootes, P.M., M. Stuiver, J.W.C. White, S. Johnson, and J. Jouzel, Comparison of oxygen istope records from the GISP2 and GRIP Greenland ice cores, Nature, 366, 552-554, 1993.

Heinrich, H., Origin and consequences of cyclic Ice rafting in the northeast Atlantic Ocean during the past 130,000 years, Quat. Res., 29 , $142-152,1988$.

Henderson, G.M., and N.C. Slowey, Evidence from U-Th datıng against Northern Hemisphere forcing of the penultimate deglaciation, Nature, 404, 61-66, 2000.

Karner, D.B., and R.A. Muller, A causality problem for Milankovitch, Science, 288, 2143-2144, 2000.

Keigwin, L.D., and E.A. Boyle, Surface and deep ocean variability in the northem Sargasso Sea during marine isotope stage 3, Paleoceanography, 14, 164-170, 1999.

Keigwin, L.D., and G.A. Jones, Glacial-Holocene stratigraphy, chronology, and paleoceanographic observations on some North Atlantic sediment drifts, Deep Sea Res., 36, 845-867, 1989.

Keigwin, L.D., and G.A. Jones, Western North Atlantic evidence for millenial-scale changes in ocean circulation and climate, Jour. Geophys. Res., 99, 12,397-12,410, 1994.

Keigwin, L.D., G.A. Jones, and S.J. Lehman, Deglacial meltwater discharge, North Atlantic deep circulation, and abrupt climate change, J. Geophys. Res., 96, 16,811-16,826, 1991.

Keigwin, L.D., W.B. Curry, S.J. Lehman, and S. Johnsen, The role of North Atlantic climate change between 70 and $130 \mathrm{kyr}$ ago, Nature, 371, 323-326, 1994.

Keigwin, L.D., D. Rio, G.D. Acton, and et al., Intermediate Depth Blake Outer Ridge sites 1056, 1057, 1058, and 1059, Proc. ODP, Init. Rept, 172, 77-135, 1998

Kellogg, T.B., Paleoclimatology and paleooceanography of the Norwegian and Greenland Seas: Glacial-interglacial contrasts, Boreas, 9, 115-137, 1980.

Labeyrie, L.D., J.-C. Duplessy, J. Duprat, A. Juillet-Leclerc, J. Moyes, E. Michel, N Kallel, and N.J. Shackleton, Changes in the vertical structure of the North Atlantic Ocean between glacial and modern times, Quat. Sci. Rev., 11, 401-413, 1992.

Lehman, S.J., and L.D. Keigwin, Sudden changes in North Atlantic circulation during the last deglaciation, Nature, 356, 757-762, 1992.

Lehman, S.J., D.G. Wright, and T. Stocker, Transport of freshwater into the deep ocean by the Conveyor, in Ice in the Climate System, NATO ASI Ser., Ser. I, vol. 12, edited by W.R. Peltier, pp. 187-209, Springer-Verlag, 1993. Liss, P.S., and L. Merlivat, Air-sea exchange rates: Introduction and synthesis, in The Role of Air-
Sea Exchange in Geochemical Cycling, edited by P. Baut-Menard, pp. 113-127, D. Reidel, Norwell, MA., 1986.

Lototskaya, A., and Ganssen, G.M. The structure of Termination II (penultimate deglaciation and Eemian) in the North Atlantic. Quat. Sci Rev., I8, 1641-1654, 1999.

MacAyeal, D.R., Growth/Purge oscillations of the Laurentide Ice Sheet as a cause of the North Atlantic's Heinrich events, Paleoceanography, 8, 775-484, 1993a.

MacAyeal, D.R., A low-order model of the Heinrich event cycle, Paleoceanography, 8, 767$773,1993 b$.

Martinson, D G , N.G. Pisıas, J D. Hays, J. Imbne, J. T. C. Moore, and N.J. Shackleton, Age dating and the orbital theory of the ice ages: Development of a high-resolution 0 to 300,000-year chronostratigraphy, Quat. Res., 27, 1-29, 1987.

Maslin, M., M. Samthein, and J.-J. Knaack, Subtropical eastem Atlantic climate during the Eemian, Naturwissenschaften, 83, 122-126, 1996.

Mayewskı, P.A, et al., Major features and forcing of high latitude Northem Hemisphere atmospheric circulation using a 110,000 year long glaciochemical series, J. Geophys. Res., 102, 26,345-26,366, 1997.

McManus, J.F., G.C. Bond, W S. Broecker, S. Johnsen, L. Labeyrie, and S. Higgins, Highresolution climate records from the North Atlantic during the last interglacial, Nature, 371 , 326-329, 1994.

McManus, J.F., D.W. Oppo, and J.L. Cullen, 0.5 Millıon years of millennial-scale climate variability in the North Atlantıc, Science, 283 971-975, 1999.

Meese, D.A., et al., Prelıminary depth-age scale of the GISP2 ice core, Spec. CRREL Rep., 94 . 1. Cold Reg. Res. and Eng. Lab., Hanover, N.H., 1994.

Mook, W.G., J.C. Bommerson, and W.H. Staverman, Carbon isotope fractionation between dissolved bicarbonate and gaseous carbon dioxide, Earth Planet. Sci. Lett., 22, 169-176, 1974.

O'Brien, S.R., P.A. Mayewski, L.D. Meeker, D.A. Meese, M.S. Twickler, and S.I. Whitlow, Complexity of Holocene climate as reconstructed from a Greenland ice core, Science, 270, 1962-1964, 1995.

Oeschger, H., J. Beer, U. Siegenthaler, and B. Stauffer, Late glacial climate history from ice cores, in Climate Processes and Climate Sensitivity, Geophys. Monogr. Ser., vol. 29, edited by J.E. Hansen and T. Takahashi, pp. 299-306, A. G. U., Washington, DC, 1984

Oppo, D.W., and S.J. Lehman, Mid-depth circulation of the subpolar North Atlantic dunng the Last Glacial Maximum, Science, 259, 1148-1152, 1993.

Oppo, D.W., M. Horowitz, and S.J. Lehman Marine core evidence for reduced deep water production during Termination II followed by a relatively stable substage $5 \mathrm{e}$ (Eemian), $\mathrm{Pa}$ leoceanography, /2, 51-63, 1997.

Oppo, D.W., J.F. McManus, and J.L. Cullen, Abrupt climate events 500,000-340,000 years ago: Evidence from subpolar North Atlantic sediments, Science, 279, 1335-1338, 1998.

Ostermann, D.R., and W.B. Curry, Calibration of stable isotopic data: An enriched $\delta^{18} \mathrm{O}$ standard used for source gas mixing detection and 
correction, Paleoceanography, 15, 353-360, 2000.

Rasmussen, T. L., E. Balbon, E. Thomsen, L. Labeyrie, and T.C.E. van Weering, Climate records and changes in deep outflow from the Norwegian Sea $\sim 150-55$ ka, Terra Nova, 11 , 60-61, 1999.

Raymo, M.E., K. Ganley, S. Carter, D.W. Oppo, and J. McManus, High latitude climate instability in the Early Pleistocene, Nature, 392. 699-702,1988.

Ruddiman, W.F., B. Molfino, A. Esmay, and E. Pokras, Evidence beanng on the mechanism of rapid deglaciation, Clim. Change, 3, 65-87, 1980

Sachs, J.P., and S.J. Lehman, Subtropical North Atlantic temperatures 60,000 to 30,000 years ago, Science, 286, 756-759, 1999.

Sarnthein, M., and R. Tiedemann, Younger Dryas-style cooling events at glacial terminations I-VI at ODP site 658: Associated benthic $\delta^{13} \mathrm{C}$ anomalies constrain meltwater hypothesis, Paleoceanography, 5, 1041-1055, 1990.

Schmittner, A., C. Appenzeller, and T.F. Stocker, Enhanced Atlantic freshwater export dunng El Niño, Geophys. Res. Lett., 27, 1163-1166. 2000.

Schulz, M., W.H. Berger, M. Sarnthein, and P.M. Grootes, Amplitude variations of 1470-year climate oscillations during the last 100,000 years linked to fluctuation of continental ice mass, Geophys. Res. Lett., 26, 3385-3388, 1999.

Seidenkrantz, M.-S., and K L. Knudsen, Eemian clımatic and hydrographical instability on a manne shelf in northem Denmark, Quat Res., 47, 218-234, 1997.

Seidenkrantz, M.-S., P. Kristensen, and K.L. Knudsen, Marine evidence for climatic instability during the last interglacial in shelf records from northwest Europe, J. Quat. Sci., $10,77-82,1995$.

Sejrup, H.P., H Haflidason, D.K. Kristensen, and $S$ J. Johnsen, Last interglacial and Holocene climatic development in the Norwegian Sea region: Ocean front movements and ice-core data, J. Quat. Sci., 10, 385-390, 1995.

Shackleton, N.J., The last interglacial in the marine and terrestrial records, Proc. $R$. Soc London, 6, 183-190, 1969.

Sirocko, F., D. Garbe-Schonberg, A. McIntyre, and B. Molfino, Teleconnections between the subtropical monsoons and high-latitude climates during the last deglaciation, Science, 272, 526-529, 1996.

Stuiver, M., and P.M. Grootes, GISP2 oxygen isotope ratios, Quat. Res., 53, 277-284, 2000.

Stuiver, M., P.M. Grootes, and T.F. Braziunas, The GISP2 d180 climate record of the past 16,500 years and the role of the sun, ocean and volcanoes, Quat. Res., 44, 341-354, 1995.

Thomson, D.J., Quadratic-inverse spectrum estimates: Applications to paleoclimatology, Philos. Trans. R. Soc. London, Ser. A, 332, 539-597, 1990.

Thouveny, N., J.D. Beaulieu, E. Bonifay, K.M. Creer, J. Guiot, M. Icole, S. Johnsen, J. Jouzel, M. Reille, T. Williams, and D. Willianson,
Clımate variatıons in Europe over the past 140 kyr deduced from rock magnetism, Nature, 371, 503-506, 1994.

Tzedakis, P.C., Long-term tree populations in northwest Greece through multiple Quaternary climatic cycles, Nafure, $364,437-440$, 1993.

Venz, K.A., D.A. Hodell, and C.S.A. Wamke, A 1.0 Myr record of Glacial North Atlantic Intermediate Water variability from ODP site 982 in the northeast Atlantic, Paleoceanography, 14, 42-52, 1999.

Wara, M.W., A.C. Ravelo, and J.S. Revenaugh, The pacemaker always rings twice, Paleoceanography, 15, 616-624, 2000

Woillard, G.M., Grande Pile Peat Bog: A continuous pollen record for the last 140,000 years, Quat. Res., 9, 1-21, 1978.

J.L. Cullen, Department of Geological Sciences, Salem State College, Salem MA 01970. (cullen@dgl.ssc.mass.edu)

L.D. Keigwin, J.F. McManus, and D.W. Oppo, Department of Geology and Geophysics, Woods Hole Oceanographic Institution, 360 Woods Hole Road, MS 23, Woods Hole, MA 02543.

(lkeigwin@whoi.edu; jmcmanus@whoi.edu; doppo@whoi.edu)

(Received April 2, 2000; revised January 11, 2001; accepted January 17, 2001.) 